\title{
Article \\ Effect of Novel Bacteriocinogenic Lactobacillus fermentum BZ532 on Microbiological Shelf-Life and Physicochemical and Organoleptic Properties of Fresh Home-Made Bozai
}

\author{
Hafiz Abdul Rasheed, Tuhanguli Tuoheti, Zhiyu Li, Mekonen Tekliye, Yongzhu Zhang and Mingsheng Dong * \\ College of Food Science and Technology, Nanjing Agricultural University, 1 Weigang Road, \\ Nanjing 210095, China; harasheed39@gmail.com (H.A.R.); tuhangul622@126.com (T.T.); \\ lizhiyu1008@163.com (Z.L.); cherinet2018@gmail.com (M.T.); 2016208018@njau.edu.cn (Y.Z.) \\ * Correspondence: dongms@njau.edu.cn; Tel.: +86-135-1253-4561; Fax: +86-25-8439-5618
}

Citation: Rasheed, H.A.; Tuoheti, T.; Li, Z.; Tekliye, M.; Zhang, Y.; Dong, M. Effect of Novel Bacteriocinogenic Lactobacillus fermentum BZ532 on Microbiological Shelf-Life and Physicochemical and Organoleptic Properties of Fresh Home-Made Bozai. Foods 2021, 10, 2120. https://doi.org/10.3390/ foods10092120

Academic Editor: Maria de Lurdes Dapkevicius

Received: 20 July 2021

Accepted: 27 August 2021

Published: 8 September 2021

Publisher's Note: MDPI stays neutral with regard to jurisdictional claims in published maps and institutional affiliations.

Copyright: (C) 2021 by the authors Licensee MDPI, Basel, Switzerland. This article is an open access article distributed under the terms and conditions of the Creative Commons Attribution (CC BY) license (https:// creativecommons.org/licenses/by/ $4.0 /)$.

\begin{abstract}
Bacteriocinogenic Lactobacillus fermentum BZ532 with novel bacteriocin LF-BZ532 was originally isolated from Chinese cereal fermented drink, showing an antimicrobial characteristic during fermentation. This study aimed to explore the in situ antimicrobial activities of L. fermentum BZ532 and co-culturing investigation against key food pathogens, i.e., Staphylococcus aureus and Escherichia coli K-12, was conducted during fresh bozai production. The growth of spoilage bacteria was suppressed and bacterial count was reduced to a significantly low level during $48 \mathrm{~h}$ of co-cultures. In situ production of antimicrobial compounds expressed positive activity against $S$. aureus and E. coli $\mathrm{K}-12$, but negative acitivity against Salmonella sp. D104. The total viable count of bozai BZLf (bozai fermented with BZ532 strain) had a comparatively lower viable count than bozai BZ-C (bozai as an experimental control without BZ532) during storage of 7 days. Titratable acidity of bozai treatments (BZ-C, BZ-Lf) was increased, while $\mathrm{pH}$ declined accordingly during storage of 7 days. The organoleptic quality of bozai BZ-C had low sensorial scores as compared with BZ-Lf during storage. In comparison with naturally fermented bozai (BZ-C), L. fermentum BZ532 (BZ-Lf) could significantly reduce the microbial spoilage and extend the shelf-life based on microbiological examination. Conclusively, L. fermentum BZ532 can be used as a bio-protective culture for improving the safety of bozai.
\end{abstract}

Keywords: bozai (Boza); Lactobacillus fermentum BZ532; co-culture; bacteriocin LF-BZ532; Staphylococcus aureus; Escherichia coli k-12

\section{Introduction}

Microbes compete for the nutrients and limited space existing in natural ecological niches. Consequently, they have developed numerous approaches to survive; production of antimicrobial compounds like bacteriocins is one of them. Bacteriocins are antimicrobial peptides/proteins synthesized ribosomally broadly dispersed in nature [1]. This peptide biodiversity is supported by numerous differences in its characterization and structures. The application of purified or semi-purified bacteriocins or bacteriocinogenic lactic acid bacteria (LAB) as protective cultures is one technological alternative to traditional preservation strategies (i.e., chemical additives). Bacteriocins are considered the most appropriate substitutes to synthetic preservatives due to their non-toxic nature to eukaryotic cells [1].

Among bacteriocinogenic lactic acid bacteria, most of the produced bacteriocins have been isolated mainly from the genus Lactobacillus, because of the diversity of its species and habitats [2]. Some findings have focused on bacteriocin production by strains of Lactobacillus fermentum (L. fermentum) and Lactobacillus salivarius (L. salivarius), which are the predominant lactobacilli in human milk and display interesting probiotic and inhibitory properties $[3,4]$.

Several strains of L. fermentum were isolated from several sources, such as conventionally fermented milk [5]. It has been one of the specific predominant lactobacilli in 
the human intestine tract [6,7]. A former clinical study exhibited that L. fermentum RC-14 played a significant role in controlling the stability of microflora [8]. Screening for potent probiotic characteristics of L. fermentum isolated from different traditional milk products. Prior studies supported that some L. fermentum shows probiotic characteristics and is a possible probiotic candidate for gastrointestinal tract-related problems $[9,10]$. L. fermentum secreted inhibitory substances, including bacteriocins, bio-surfactants, and $\mathrm{H}_{2} \mathrm{O}_{2}$, to inhibit the growth of urogenital and intestinal pathogens $[10,11]$. The clinical findings revealed that L. fermentum was effective in reducing intestinal pathogenic microbes and increasing the ratio of probiotic bacteria in healthy individuals [11]. L. fermentum antimicrobial attributes and specific production of antimicrobial compounds (called fermenticins) are described as potential possible means for food preservation and medical application [12]. The genus Lactobacillus and species L. fermentum have been subjected to a safety risk assessment under the scientific committee of the European Food Safety Authority (EFSA) and approved on the QPS-recommended list (qualified presumption of safety) and certified to be applied to different food systems [13].

The World Health Organization (WHO) designates that Campylobacter, enterohemorrhagic Escherichia coli (E. coli), Salmonella, Listeria monocytogenes (L. monocytogenes), and Vibrio cholerae are among the most common foodborne bacteria that severely affect millions of people around the globe [14]. Milk and cereal products that are not produced with appropriate hygienic conditions can be contaminated with food pathogens like $L$. monocytogenes, Campylobacter jejuni, Salmonella spp., and E. coli O157:H7, causing foodborne outbreaks. Among others, E. coli is a foodborne pathogen of major concern for the cereal and dairy industry. Most strains of E. coli remain non-pathogenic in the intestinal tract. However, some strains may cause infections in the urinary tract, gastroenteritis, meningitis, and septicemia. E. coli O157:H7, which belongs to the enterohemorrhagic E. coli (EHEC) class, is the most pathogenic serotype of E. coli [14].

The appropriate hygiene applications are compulsory to reduce potential contamination during food production. However, good manufacturing practices may not be sufficient to ensure the safety of food products. In this approach, the food industry has been adopting alternatives to decrease contamination and regulate the growth of microbes that may reach food during the production chain, such as bacteriocins secreted by lactic acid bacteria [15]. In previous and current decades, studies on the usage of bacteriocins indicate that they can provide several benefits in food products, such as decreasing the risk of proliferation of food spoilage pathogens, extending the shelf-life and safety of the end products, and limiting the use of synthetic chemical preservatives [15-17]. Currently, there is some bacteriocin that can be used commercially as a food preservative for the control of foodborne spoilage microorganisms in various food systems, thanks to its GRAS (generally recognized as safe) status; the use of nisin in food production is approved in approximately fifty countries [18-20]. These restrictions of alternatives have stimulated numerous researchers to characterize novel bacteriocinogenic strains and their bacteriocins focused on a potential application as food bio-preservatives in different food systems.

The most extensively grown millet species around the globe is pearl millet (Pennisetum glaucum L. R. Br.), followed by foxtail (Setaria italica L.) [21,22]. In comparison with some other cereals, millet is comprised of a high fiber percentage, mineral composition, and protein quality, which considerably contribute to the nutritional security of the population existing in the millet cultivating regions [23]. Moreover, millet is not only higher in nutritional value, but also superior to the key cereals in terms of protein, vitamins, minerals, and energy [24]. Additionally, millet is recommended as a good source of nutraceuticals, phytochemicals dietary fiber, and micronutrients.

Bozai/Boza is a drink that has been produced from the fermentation of millet, maize, and barley, among others. Cooked cereal is inoculated either with specific microbial culture or previously prepared bozai or sourdough as a starter. The sludge is fermented at $30-37{ }^{\circ} \mathrm{C}$ for $24 \mathrm{~h}$ and kept at $4{ }^{\circ} \mathrm{C}$ for $2-3$ days, as reported previously $[25,26]$. In our previous study, bozai has been explored in terms of bacteriocinogenic nature and 
the same fermentation method as "Boza" was reported, which is widely reported in different countries [27]. It produces the bacteriocin LF-BZ532, which has been previously characterized [27]. This bacteriocin shows the inhibitory activity against several food pathogens such as Escherichia coli K-12 (E. coli K-12), Staphylococcus aureus ATCC6538 (S. aureus ATCC6538), and Listeria monocytogenes.

This study aimed to investigate the effect of bacteriocinogenic Lactobacillus fermentum BZ532 strain (L. fermentum BZ532) on freshly prepared bozai, specifically with regards to co-culturing of BZ532 strain against food spoilage microorganisms, i.e., E. coli, S. aureus, in situ bacteriocin production evaluation by agar well diffusion assay against key food pathogens, and physicochemical and sensory evaluation with and without bacteriocinogenic L. fermentum BZ532.

\section{Materials and Methods}

Millet seeds (Pennisetum glaucum L. R. Br.) as a raw material to produce fresh bozai were purchased from a local market located in Nanjing, China.

\subsection{Bacterial Strains and Culture Conditions}

L. fermentum BZ532 is a bacteriocinogenic strain isolated from the fermented beverage named bozai. L. fermentum BZ532 was grown in De Man, Rogosa, and Sharpe (MRS) broth Merk, Darmstadt, Germany) at $37^{\circ} \mathrm{C}$ for $24 \mathrm{~h}$, as previously described [27]. E. coli K-12, S. aureus ATCC6538, and Salmonella sp. D104 were used as indicator strains in the present study and activated as reported previously [27].

\subsection{Fresh Bozai Production}

Millet seeds were purchased from a local market located in Nanjing, China, and immediately delivered to our lab under aseptic conditions. Millet seeds were washed with sterile water and soaked overnight in sterile water. Afterward, they were cooked in boiling water with continuous stirring for 20-30 min. Then, the mixture was homogenized and water was added to reach the required consistency. The mixture was further strained for removing the solid phase and sugar (5\%) was added to the liquid phase. Finally, the sweet liquid was inoculated with an overnight culture of L. fermentum BZ532 in MRS $\left(10^{5} \mathrm{CFU} / \mathrm{mL}, 1 \% v / v\right)$ and incubated for $24 \mathrm{~h}$ at $37^{\circ} \mathrm{C}$ (Figure 1). Moreover, four bozai treatments, co-culturing the BZ532 strain with two food pathogenic strains (E. coli K-12 and S. aureus ATCC6538), were prepared separately for co-culturing study; i.e., first, control bozai was inoculated with mono-culture of S. aureus and its treatment co-culture the BZ532 strain with $S$. aureus in bozai; Second, control bozai was inoculated with mono-culture of E. coli and its treatment co-culture the BZ532 strain with E. coli, in order to study their antimicrobial effect. An additional bozai treatment was also produced as an experimental control by natural fermentation (sourdough starter), without the addition of L. fermentum BZ532, for physicochemical and organoleptic evaluation. Microbiological (TVC and LAB count), physicochemical, and organoleptic evaluations were performed at 1,3,5, and 7 days of storage at $4{ }^{\circ} \mathrm{C}$.

\subsection{Microbiological Analysis}

\subsubsection{Total Viable Count (TVC) and LAB Enumeration}

The bozai sample of different treatments was procured on storage days 1,3,5, and 7 to determine the TVC. In brief, $10 \mathrm{~g}$ of bozai sample was homogenized in $90 \mathrm{~mL}$ of $0.85 \%$ $\mathrm{NaCl}(w / v)$ sterilized saline and ten-fold dilutions were performed with the same saline. Different dilutions were pour plated on plate count agar (PCA; Oxoid), and then incubated at $37^{\circ} \mathrm{C}$ for $24 \mathrm{~h}$. The results were expressed as $\log \mathrm{CFU} / \mathrm{g}$. LAB populations were counted by pour plate of particular dilutions on MRS agar and incubated at $37^{\circ} \mathrm{C}$ for $36 \mathrm{~h}$; the colonies were enumerated after a specific incubation time and the results were expressed in CFU/g according to previously reports $[28,29]$. 


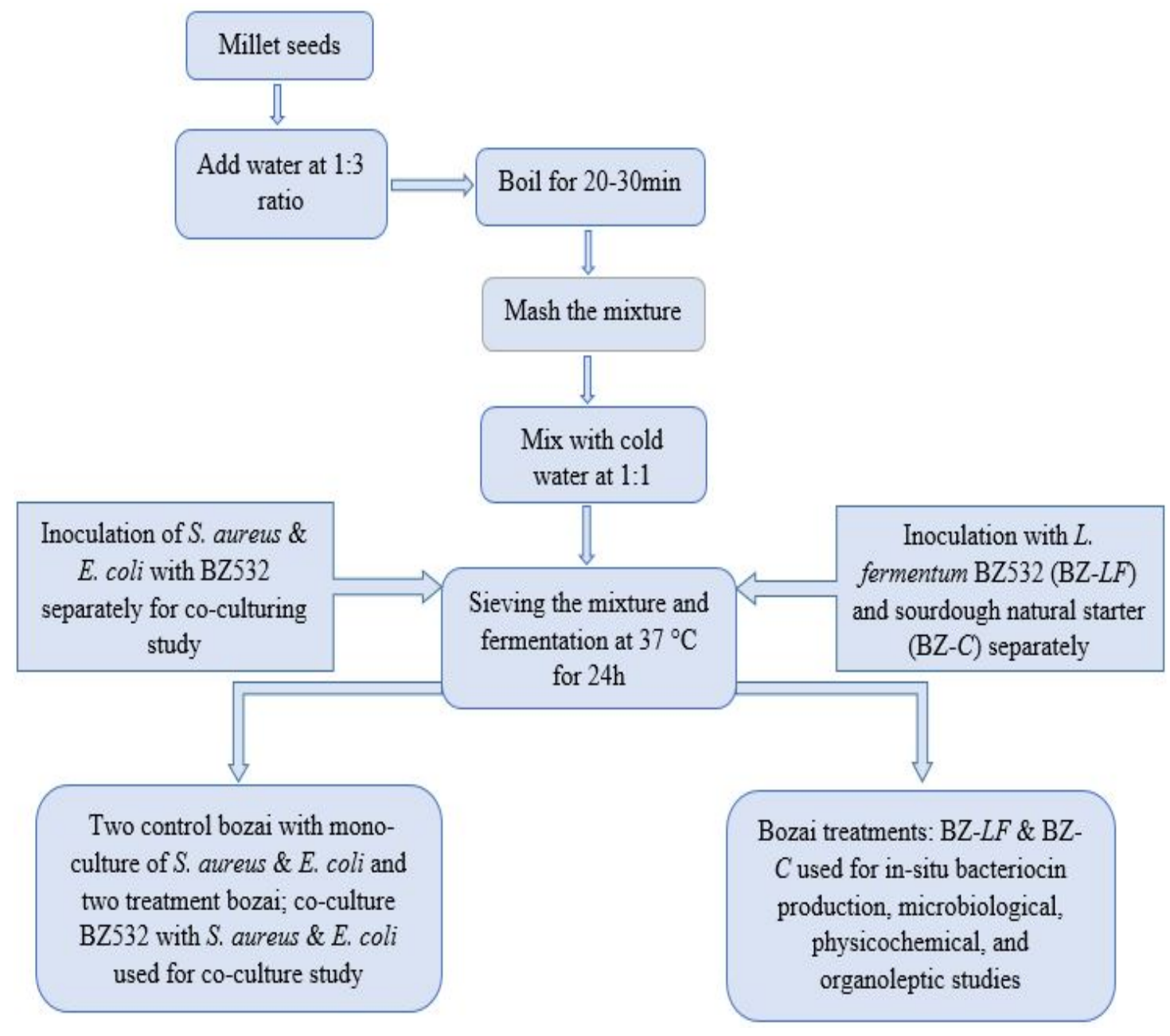

Figure 1. Flow diagram of bozai production.

2.3.2. Co-Culturing of L. fermentum BZ532 with Pathogenic Bacteria during Bozai Production

Two food pathogen indicator strains (S. aureus and E. coli K-12) and L. fermentum BZ532 were inoculated simultaneously to produce fresh bozai at a level of $10^{4} \mathrm{CFU} / \mathrm{mL}$ of indicator strains and $10^{5} \mathrm{CFU} / \mathrm{mL}$ for bacteriocinogenic BZ532, respectively, and then incubated $(48 \mathrm{~h})$ at $37^{\circ} \mathrm{C}$. Enumeration of various strains was conducted at specific incubation intervals of $0,4,8,12,24,36$, and $48 \mathrm{~h}$ by pouring specific ten-fold dilution on Baird-Parker agar (BP; Oxoid) for S. aureus, violet red bile glucose agar (VRBG; Oxoid, Basingstoke, UK) for E. coli K-12, and MRS agar for L. fermentum BZ532, and then incubated for $48 \mathrm{~h}$ at $37^{\circ} \mathrm{C}$.

\subsubsection{In Situ Production of Bacteriocin Antimicrobial Compounds}

The bacteriocin LF-BZ532 produced in bozai fermented by the strain L. fermentum BZ532 was evaluated according to the method of Castilho et al. [30], with some modifications. Bozai sample $(10 \mathrm{~g})$ was homogenized with $10 \mathrm{~mL}$ of $0.02 \mathrm{~N} \mathrm{HCl}$ and centrifuged $\left(12,000 \times g, 15 \mathrm{~min}, 4^{\circ} \mathrm{C}\right)$. The $\mathrm{pH}$ of attained cell-free supernatant (CFS) was set to 6.0 with $4 \mathrm{~N} \mathrm{NaOH}$ and lyophilized. Afterward, $5 \mu \mathrm{g}$ lyophilized CFS was diluted with $150 \mu \mathrm{L}$ of Ringer $\times 1 / 4$ and $40 \mu \mathrm{L}$ of this CFS was transferred to wells of different test plates inoculated with three indicator strains of S. aureus $\left(10^{6} \mathrm{CFU} / \mathrm{mL}\right)$, E. coli. K-12 $\left(10^{6} \mathrm{CFU} / \mathrm{mL}\right)$, and Salmonella sp. D104 ( $\left.10^{6} \mathrm{CFU} / \mathrm{mL}\right)$ on BP $(0.7 \%$ agar $)$, VRBG $(0.7 \%$ agar), and LB $(0.7 \%$ agar) medium, respectively. Then, they were incubated at $37^{\circ} \mathrm{C}$ for $24 \mathrm{~h}$ and inhibition zones were observed to detect the production of bacteriocin in the tested bozai samples. 


\subsection{Physicochemical Evaluation of Bozai}

All the treatments of bozai from 1 to 7 days of storage were subjected to physicochemical analysis, i.e., titratable acidity, $\mathrm{pH}$, and protein content according to AOAC methods [31].

\subsubsection{Titratable Acidity}

The obtained samples of bozai were subjected to potentiometric titration with $0.1 \mathrm{~N}$ $\mathrm{NaOH}$ up to $\mathrm{pH} 8$ to analyze the total titratable acidity according to AOAC methods with some modifications [31]. All samples including control and treatment groups were evaluated in duplicate and the results were calculated according to the following formula and expressed as \% lactic acid.

$\%$ acid $=[(\mathrm{ml}$ of $\mathrm{NaOH}$ used $] \times[0.1 \mathrm{~N} \mathrm{NaOH}] \times$ milliequivalent factor $\times 100)] /$ grams of sample.

\subsection{2. $\mathrm{pH}$}

The $\mathrm{pH}$ was determined using a digital $\mathrm{pH}$ meter (PHS-3C, Shanghai, China) according to the method described by [32,33]. In brief, $5 \mathrm{~g}$ of bozai sample was diluted in $20 \mathrm{~mL}$ of neutral distilled water and homogenized. The $\mathrm{pH}$ meter was calibrated against buffer solution ( $\mathrm{pH} 4$ and 6.86).

\subsubsection{Total Protein Content}

The total protein in terms of the crude protein content of bozai samples was determined according to the Kjeldahl method with some modifications and multiplied by a constant factor of 6.25 to quantify the crude protein proportion [32,33].

\subsection{Organoleptic Evaluation}

The organoleptic properties of bozai treatments (BZ-C, bozai without L. fermentum BZ532 and BZ-Lf, bozai fermented with L. fermentum BZ532) were evaluated by ten panelists according to the process described by [34] with slight modification. Color, odor, mouthfeel, and overall acceptability of bozai samples were evaluated and scores were assigned on a hedonic scale from 1 (extremely dislike) to 9 (extremely like), as previously reported [34].

\subsection{Statistical Analysis}

All experiments were carried out in triplicate and the result was expressed as a mean \pm standard deviations (SD), and all data were compared to check the significance by ANOVA $(p<0.05)$ and Tukey's $t$-test by software STATISTIX 8.1.

\section{Results and Discussion}

\subsection{Changes in TVC and L. fermentum BZ532 Enumeration during Bozai Storage}

TVC is extensively used as a key parameter to evaluate the general quality status of the fermented product of any origin. Changes in TVC of bozai are presented in Figure 2a. TVCs of two bozai treatments (BZ-C and BZ-Lf) were 4.8 and $4.43 \log \mathrm{CFU} / \mathrm{mL}$, respectively, at day 0 . All bozai samples were evaluated throughout 7 days of storage at $4{ }^{\circ} \mathrm{C}$ and the control group of bozai (BZ-C) treatment showed a steady increase, BZ-C expressed the highest value, and BZ-Lf showed the minimum as compared with the BZ-C group. The TVCs of BZ$C$ reached $7.22 \log \mathrm{CFU} / \mathrm{mL}$ on day 7 ; instead, BZ-Lf showed $5.03 \log C F U / \mathrm{mL}$, relatively lower than the control group of bozai, indicating that the bacteriocinogenic strain with the antimicrobial product had a substantial inhibition effect on TVC of bozai, which followed the findings of previously studies $[35,36]$. The microbiological standard of fermented food products was standardized at $6 \log \mathrm{CFU} / \mathrm{mL}$ [37]; according to standardized values, the results of BZ-C bozai exceed that limit, but accordingly, BZ-Lf is still edible. These results exhibited that the antimicrobial product could prolong the shelf-life of bozai by inhibiting the viable count of bacteria. 


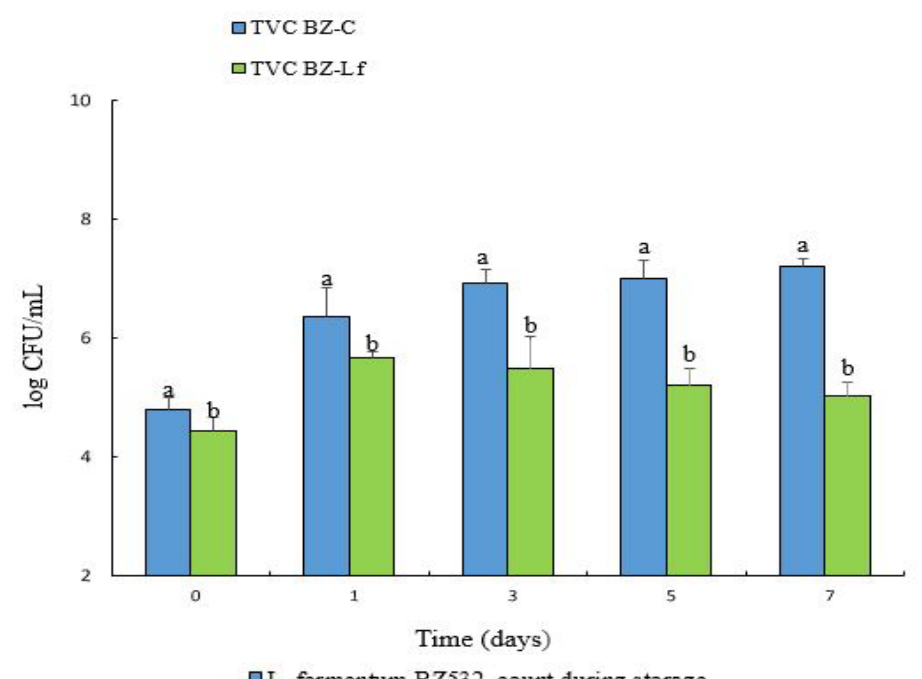

(A)

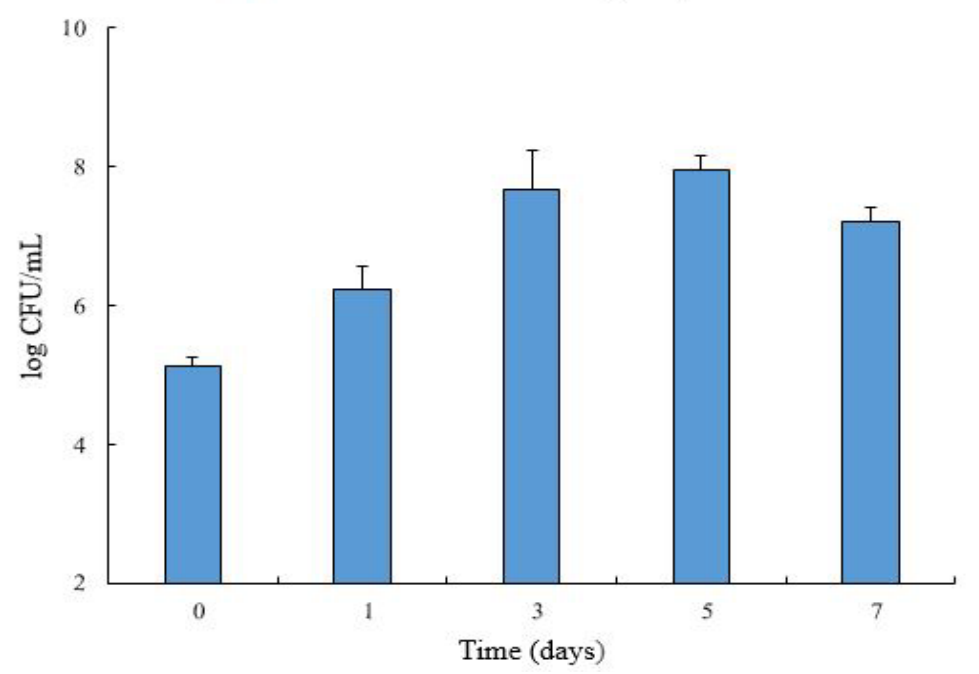

(B)

Figure 2. Changes in (A) TVC of bozai treatments and (B) LAB enumeration during storage of 7 days at $4{ }^{\circ} \mathrm{C}$. Data with different letters represent significant differences $(p<0.05)$.

L. fermentum BZ532 counts in bozai beverage during 7 days of storage at $4{ }^{\circ} \mathrm{C}$ are shown in Figure 2b. The count level increased from 5.11 to $7.95 \log \mathrm{CFU} / \mathrm{mL}$ in the first five days of storage at $4{ }^{\circ} \mathrm{C}$, then gradually decreased to $7.19 \log \mathrm{CFU} / \mathrm{mL}$ ) after 7 days. The evolution of the lactic acid strain level in bozai is dependent on storage time and temperature, as previously observed by other authors [38]. These microorganisms have played a substantial role in food fermentations, leading to texture and flavor change together with a preservative effect, increasing the shelf-life of the altered product [17].

\subsection{Co-Culturing of L. fermentum BZ532 with Pathogenic Bacteria during Bozai Production}

The bacteriocin LF-BZ532 produced by the strain L. fermentum BZ532 has been preliminarily characterized in a previous study [27]. The inhibition spectrum of BZ532 was assessed by co-culturing the BZ532 strain against pathogenic strains such as $S$. aureus ATCC6538 and E. coli k-12 separately. To test the ability of L. fermentum BZ532 as a protective culture, fresh bozai BZ-LF was inoculated simultaneously with indicator pathogen strains cited above. For control purposes, mono-cultures of bozai BZ-C with S. aureus ATCC6538 and E. coli k-12 were also performed separately. S. aureus ATCC6538 presented a prompt growth rate from 3.82 to $7.11 \log \mathrm{CFU} / \mathrm{mL}$ during a mono-culture of $48 \mathrm{~h}$. Meanwhile, the growth rate of S. aureus ATCC6538 during co-culturing with L. fermentum BZ532 showed a slight rise, then significantly $(p<0.05)$ reduced to a level of $3.85 \log \mathrm{CFU} / \mathrm{mL}$ within $24 \mathrm{~h}$ of fermentation, as stated in Figure 3a. Microbial growth of E. coli was increased 
2-3 $\log \mathrm{CFU} / \mathrm{mL}$ during monoculture in bozai; however, a limited increase was observed during co-culturing from 3.95 to $4.53 \mathrm{log}$ with bacteriocinogenic L. fermentum BZ532 during the initial $8 \mathrm{~h}$ (Figure $3 \mathrm{~b}$ ), then declining gradually afterward. However, no effect on L. fermentum BZ532 growth was observed during co-culturing. Similar results were previously described $[35,39]$.

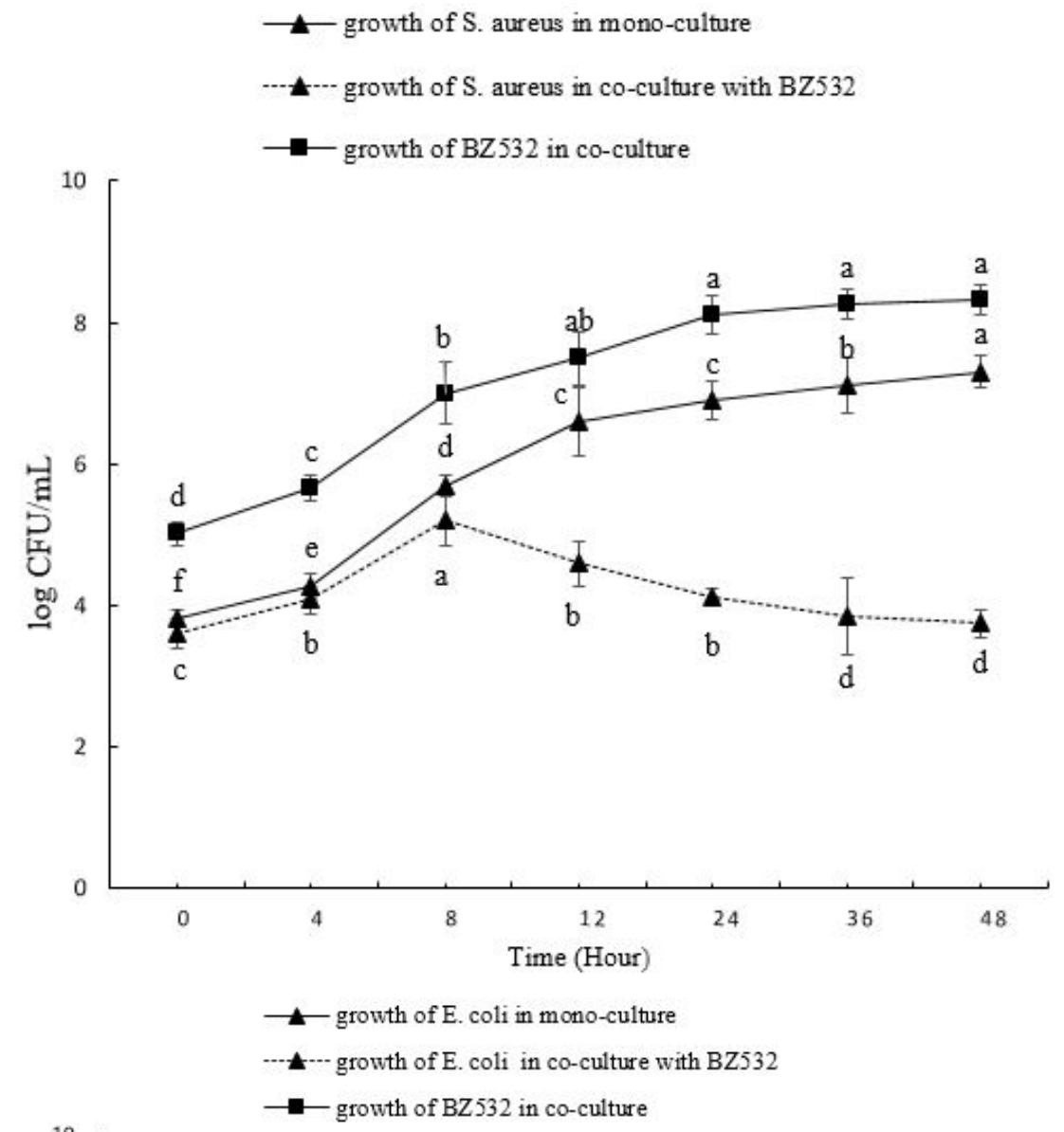

(A)

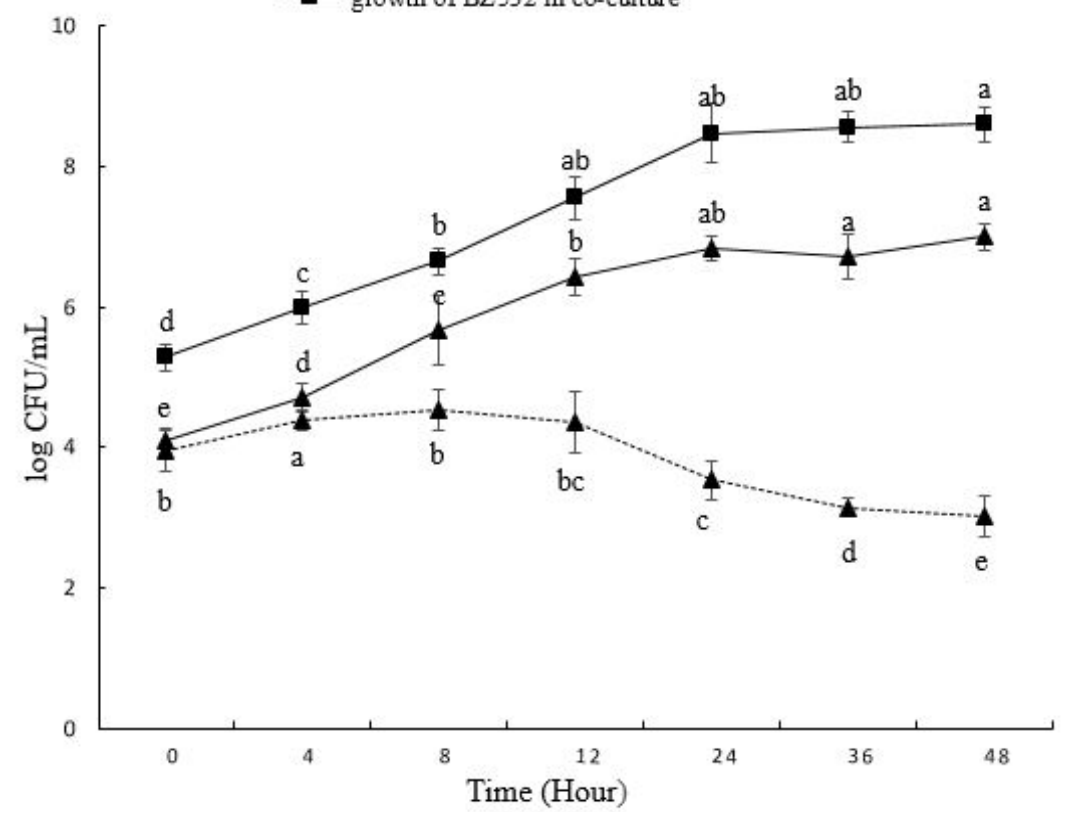

(B)

Figure 3. Co-culturing of L. fermentum BZ532 strain against pathogenic strains (A) S. aureus and (B) E. coli in bozai treatments during $48 \mathrm{~h}$ fermentation. Data with different letters represent significant differences $(p<0.05)$. 
A significant decrease in the growth of two indicator strains was detected in cocultures with L. fermentum BZ532, and food spoilage strains were inhibited during bozai fermentation. The antimicrobial peptides produced during fermentation accumulated continuously, leading to increased antimicrobial potential. A comprehensive mechanism is needed to validate this in further studies. These results recognized that $L$. fermentum BZ532 can used as a protective culture in bozai to limit the growth of pathogenic food spoilage microbes.

\subsection{In Situ Bacteriocin Activities in Bozai during Storage}

The application of bacteriocinogenic strains as a protective culture is based on in situ production of bacteriocins in several reported studies [30,40]. CFS extracted from bozai treatments showed antimicrobial activities, the neutralized CFS of bozai BZ-LF treatment showed a wide range inhibitory spectrum against S. aureus ATCC6538 and E. coli, but not against Salmonella sp. D104, as presented in Table 1. In Figure 4, this was varied from LF-BZ532 produced by L. fermentum BZ532 in MRS (broth) medium, which expressed strong inhibition against Salmonella sp. D104 [27]. The production of bacteriocins might be intensively affected by the composition of the growth medium [16]. Bozai treatment with bacteriocinogenic strain inoculation presented in situ bacteriocin production against two pathogens, as stated previously. However, generally, LAB can produce different organic products such as organic acids (lactic acid, propionic acid, acetic acid, and so on), acetaldehyde, diacetyl, and bacteriocins with antimicrobial characteristics [41]. Bacteriocins are ribosomally synthesized antimicrobial peptides/proteins, showing a diverse activity spectrum. Several bacteriocins produced by LAB strains have been documented and proved to be effective against S. aureus, L. monocytogenes, Bacillus sp., Clostridium sp., and other spoilage microbes [42]. Numerous LAB strains from cereal-based products have been recognized as a good producer of antimicrobial compounds against different foodborne pathogens; i.e., E. coli, L. monocytogenes, and S. aureus, among others [43].

Table 1. In situ antimicrobial activities of prepared bozai treatments.

\begin{tabular}{|c|c|c|c|c|c|c|}
\hline \multirow{3}{*}{ Indicator Strains } & \multicolumn{6}{|c|}{ Antimicrobial Activities 1} \\
\hline & \multicolumn{2}{|c|}{$24 \mathrm{~h}$} & \multicolumn{2}{|c|}{$36 \mathrm{~h}$} & \multicolumn{2}{|c|}{$48 \mathrm{~h}$} \\
\hline & BZ-C & BZ-LF & BZ-C & BZ-LF & BZ-C & BZ-LF \\
\hline Staphylococcus aureus & $1.66 \pm 0.21^{b}$ & $3.32 \pm 0.08^{a}$ & $1.81 \pm 0.17^{b}$ & $4.85 \pm 0.10^{\mathrm{a}}$ & $1.93 \pm 0.15^{b}$ & $5.54 \pm 0.13^{a}$ \\
\hline Escherichia coli k-12 & $1.84 \pm 0.15^{b}$ & $3.64 \pm 0.06^{\mathrm{a}}$ & $1.98 \pm 0.17^{b}$ & $5.36 \pm 0.13^{a}$ & $2.09 \pm 0.22^{b}$ & $5.64 \pm 0.09^{a}$ \\
\hline Salmonella sp. D104 & $1.02 \pm 0.16^{\mathrm{a}}$ & $0 \pm 0^{b}$ & $1.11 \pm 0.13^{\mathrm{a}}$ & $0 \pm 0^{b}$ & $1.26 \pm 0.21^{\mathrm{a}}$ & $0 \pm 0^{b}$ \\
\hline
\end{tabular}

Data with different letters represent significant differences $(p<0.05) .{ }^{1}$ Antimicrobial activities: diameter of inhibition zones (mm); values expressed as means $\pm \mathrm{SD}(n=3)$.
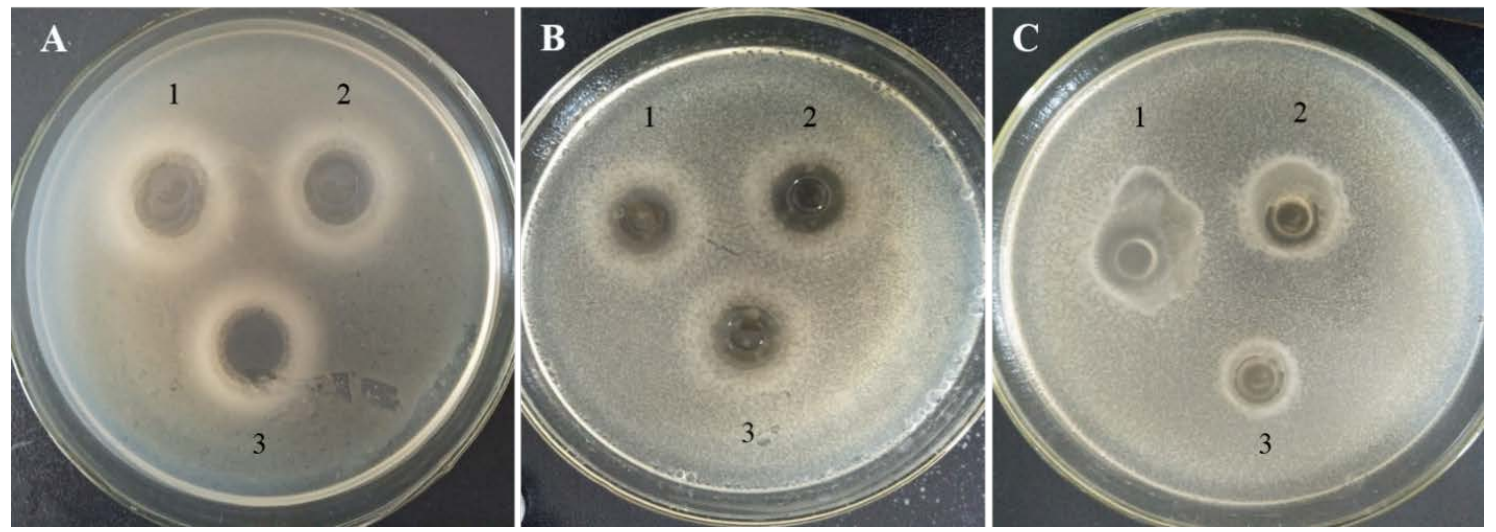

Figure 4. Antimicrobial action of in situ production of bacteriocin in bozai BZ-LF against (A) S. aureus, (B) E. coli k-12, and (C) Salmonella sp. D104. 1, 2, 3 represents as triplicate of inhibition zone $(n=3)$. 
Based on this study, L. fermentum BZ532 can inhibit the growth of E. coli and S. aureus in the fresh bozai production system thanks to its bacteriocinogenic ability during storage; however, it was not able to counter the activity of Salmonella sp. in fresh bozai. Further studies must be directed to evaluate the inhibitory spectrum of L. fermentum BZ532 bacteriocin at various concentrations with advanced methodology.

\subsection{Changes in Physicochemical Parameters of Bozai during Storage}

The effect of bacteriocinogenic activity and storage on $\mathrm{pH}$ and acidity is presented in Table 2. $\mathrm{pH}$ and titratable acidity are inversely correlated parameters. Moreover, the $\mathrm{pH}$ of bozai samples declined, while the total acidity percentage indicated a significant $(p<0.05)$ increase during fermentation and storage, as presented in Table 2 , with initial $\mathrm{pH}$ and acidity between 5.75 and 4.51 and $0.89 \%$ and $2.37 \%$, respectively, in the control BZ-C and BZ-Lf group of bozai. The $\mathrm{pH}$ decreased slightly from 5.75 to 5.11 in the control group of bozai (BZ-C), but a significant decline from 4.51 to 3.11 in the BZ-LF group was observed during 7 days of storage at $4{ }^{\circ} \mathrm{C}$. As $\mathrm{pH}$ and titratable acidity are inversely correlated, the initial acidity of BZ-LF was $2.37 \%$; thereafter, it increased to $3.88 \%$. BZ-Lf treatments were also observed in terms of their acidity percentage changes during storage and showed a significant increase in acidity level during 7 days of storage. A significant $(p<0.05)$ decrease in $\mathrm{pH}$ of bozai samples was due to the specific microbiological activity of L. fermentum BZ532 in terms of their lactic acid production by glycolysis of various carbohydrates during fermentation and storage. The findings are compatible with previously reported studies that were targeted to optimize different cereal-based probiotic food products [44-47]. Food formulations with $\mathrm{pH}$ levels (3.5-4.5) are desired because they boost the stability and benefits of probiotic microbes [48] as well as inhibit the growth of coliforms [49].

Table 2. Changes in physicochemical parameters of Bozai samples during storage of 7 days at $4{ }^{\circ} \mathrm{C}$.

\begin{tabular}{cccccc}
\hline \multirow{2}{*}{ Parameters } & Treatments & \multicolumn{4}{c}{ Storage Time (Days) } \\
\cline { 2 - 6 } & & $\mathbf{1}$ & $\mathbf{3}$ & $\mathbf{5}$ \\
\hline \multirow{2}{*}{$\mathrm{pH}$} & BZ-C & $5.75 \pm 0.13^{\mathrm{a}}$ & $5.47 \pm 0.08^{\mathrm{a}}$ & $5.22 \pm 0.09^{\mathrm{a}}$ & $5.11 \pm 0.11^{\mathrm{a}}$ \\
\cline { 2 - 6 } & BZ- $f f$ & $4.51 \pm 0.11^{\mathrm{b}}$ & $3.85 \pm 0.10^{\mathrm{b}}$ & $3.25 \pm 0.06^{\mathrm{b}}$ & $3.11 \pm 0.06^{\mathrm{b}}$ \\
\hline \multirow{2}{*}{ Total acidity (\%) } & BZ-C & $0.89 \pm 0.08^{\mathrm{b}}$ & $1.36 \pm 0.04^{\mathrm{b}}$ & $1.70 \pm 0.08^{\mathrm{b}}$ & $1.89 \pm 0.07^{\mathrm{b}}$ \\
\cline { 2 - 6 } & BZ- $f f$ & $2.37 \pm 0.13^{\mathrm{a}}$ & $3.14 \pm 0.04^{\mathrm{a}}$ & $3.69 \pm 0.14^{\mathrm{a}}$ & $3.88 \pm 0.07^{\mathrm{a}}$ \\
\hline \multirow{2}{*}{ Protein (\%) } & BZ-C & $3.26 \pm 0.41^{\mathrm{b}}$ & $2.82 \pm 0.38^{\mathrm{b}}$ & $3.15 \pm 0.31^{\mathrm{b}}$ & $2.69 \pm 0.21^{\mathrm{b}}$ \\
\cline { 2 - 6 } & BZ- $L f$ & $3.07 \pm 0.51^{\mathrm{a}}$ & $2.99 \pm 0.23^{\mathrm{a}}$ & $3.18 \pm 0.33^{\mathrm{a}}$ & $2.87 \pm 0.26^{\mathrm{a}}$ \\
\hline
\end{tabular}

Results expressed as means \pm SD $(n=3)$. Data with different letters represent significant differences $(p<0.05)$.

The changes in protein content of bozai with the effect of bacteriocinogenic strain are presented in Table 2. The maximum protein content of the control bozai BZ-C group was $3.26 \%$; however, BZ-Lf had 3.18\%. It is indicated that no significant $(p<0.05)$ effect of the bacteriocinogenic strain was explored on the protein content, as no consistent changes in total protein content were observed during fermentation and storage.

\subsection{Changes in Organoleptic Properties of Bozai during Storage}

The effect of bacteriocinogenic strain and storage days on sensory attributes of bozai is presented in Table 3. It was determined that storage time and antimicrobial compounds had a significant $(p<0.05)$ effect on the organoleptic characteristics (color, odor, mouthfeel, and overall acceptability) of bozai. As likely, a decline in sensory scores of bozai treatments during storage was exhibited, demonstrating a slight decrease in overall acceptability. All of the bozai treatments exhibited maximum sensory scores at storage day 1 , with a decrease during storage of 7 days, and indicated that antimicrobial products did not have any adverse effect on bozai quality at day 1 . The highest sensory score of the BZ-Lf bozai group at day 1 in terms of color was 6.55, while the odor and mouthfeel score was 6.33 and 6.63, 
respectively, as presented in Table 3. The highest overall acceptability score of bozai BZ-Lf was 6.66; however, the control group of bozai BZ-C showed the lowest overall acceptability of 5.60, a clear indication of the significant $(p<0.05)$ effect of bacteriocinogenic strain with antimicrobial compounds on bozai treatments of BZ-Lf. The results of various sensory parameters revealed that the bacteriocinogenic strain with bacteriocin could positively affect the overall quality of bozai during storage of 7 days. In conclusion, these findings presented that consumers may accept LAB bozai as a natural functional cereal beverage.

Table 3. Changes in organoleptic properties of Bozai samples during storage of 7 days at $4{ }^{\circ} \mathrm{C}$.

\begin{tabular}{|c|c|c|c|c|c|}
\hline \multirow{2}{*}{ Parameters } & \multirow{2}{*}{ Treatments } & \multicolumn{4}{|c|}{ Storage Time (Days) } \\
\hline & & 1 & 3 & 5 & 7 \\
\hline \multirow{2}{*}{ Color } & BZ-C & $5.76 \pm 0.40^{b}$ & $4.88 \pm 0.32^{b}$ & $5.1 \pm 0.17^{b}$ & $4.66 \pm 0.23^{b}$ \\
\hline & $\mathrm{BZ}-L f$ & $6.55 \pm 0.23^{a}$ & $5.70 \pm 0.20^{a}$ & $5.93 \pm 0.40^{a}$ & $5.53 \pm 0.50^{a}$ \\
\hline \multirow{2}{*}{ Odour } & $\mathrm{BZ}-\mathrm{C}$ & $4.26 \pm 0.46^{b}$ & $4.56 \pm 0.40^{b}$ & $4.66 \pm 0.57^{b}$ & $5.66 \pm 0.57^{b}$ \\
\hline & $\mathrm{BZ}-L f$ & $6.33 \pm 0.57^{a}$ & $5.56 \pm 0.51^{\mathrm{a}}$ & $6.50 \pm 0.5^{a}$ & $6.83 \pm 0.76^{a}$ \\
\hline \multirow{2}{*}{ Mouthfeel } & BZ-C & $5.26 \pm 0.64^{b}$ & $5.13 \pm 0.80^{b}$ & $4.86 \pm 0.80^{b}$ & $4.56 \pm 0.51^{b}$ \\
\hline & BZ-Lf & $6.63 \pm 0.47^{\mathrm{a}}$ & $5.86 \pm 0.51^{\mathrm{a}}$ & $6.46 \pm 0.45^{\mathrm{a}}$ & $5.66 \pm 0.57^{a}$ \\
\hline \multirow{2}{*}{ Overall acceptability } & $\mathrm{BZ}-\mathrm{C}$ & $5.60 \pm 0.36^{b}$ & $5.5 \pm 0.86^{b}$ & $5.5 \pm 0.5^{b}$ & $5.20 \pm 0.34^{b}$ \\
\hline & $\mathrm{BZ}-L f$ & $6.66 \pm 0.76^{a}$ & $6.06 \pm 0.4^{\mathrm{a}}$ & $6.0 \pm 0.30^{a}$ & $5.93 \pm 0.40^{\mathrm{a}}$ \\
\hline
\end{tabular}

Results are expressed as means \pm SD $(n=3)$. Data with different letters represent significant differences $(p<0.05)$.

\section{Conclusions}

A bozai drink was developed by inoculation of L. fermentum BZ532 and compared with a control group of bozai with natural starter (Sourdough) inoculation. L. fermentum BZ532 showed significant antimicrobial activity against foodborne pathogens such as $S$. aureus and E. coli during the co-culturing study, and in situ production of antimicrobial compounds also had an antimicrobial effect on two food spoilage microbes, i.e., S. aureus and E. coli. The microbiological status of bozai treatments concerning TVC and BZ532 count was also determined during storage. Bozai treatments (BZ-C and BZ-LF) were also subjected to physicochemical characteristics in terms of $\mathrm{pH}$, titratable acidity, and protein content. Overall acceptability of bozai treatments was also determined by evaluating several organoleptic parameters, and it was found that the BZ-LF bozai had significantly high acceptability by the expert panelists.

Author Contributions: Writing—original draft, Formal Analysis and Investigation: H.A.R.; Resources, Review and Editing: T.T.; Software, Data Curation: Z.L.; Resources, Review and Editing: M.T.; Visualization, Resources: Y.Z.; Conceptualization, Supervision and Validation: M.D. All authors have read and agreed to the published version of the manuscript.

Funding: This work was supported by Priority Academic Program Development of Jiangsu Higher Education Institutions (PAPD), China.

Institutional Review Board Statement: Not Applicable.

Informed Consent Statement: Not Applicable.

Data Availability Statement: Data is contained within the article.

Conflicts of Interest: The authors declare that they have no conflict of interest regarding this manuscript. 


\section{References}

1. Yildirim, Z.; Bilgin, H.; Isleroglu, H.; Tokatli, K.; Sahingil, D.; Yildirim, M. Enterocin HZ produced by a wild Enterococcus faecium strain isolated from a traditional, starter-free pickled cheese. J. Dairy Res. 2014, 81, 164. [CrossRef]

2. De Vuyst, L.; Callewaert, R.; Pot, B. Characterization of the antagonistic activity of Lactobacillus amylovorus DCE 471 and large scale isolation of its bacteriocin amylovorin L471. Syst. Appl. Microbiol. 1996, 19, 9-20. [CrossRef]

3. Kang, M.-S.; Lim, H.-S.; Oh, J.-S.; Lim, Y.-j.; Wuertz-Kozak, K.; Harro, J.M.; Shirtliff, M.E.; Achermann, Y. Antimicrobial activity of Lactobacillus salivarius and Lactobacillus fermentum against Staphylococcus aureus. Pathog. Dis. 2017, 75, ftx009. [CrossRef]

4. Asan-Ozusaglam, M.; Gunyakti, A. Lactobacillus fermentum strains from human breast milk with probiotic properties and cholesterol-lowering effects. Food Sci. Biotechnol. 2019, 28, 501-509. [CrossRef] [PubMed]

5. Abdelgadir, W.S.; Hamad, S.H.; Møller, P.L.; Jakobsen, M. Characterisation of the dominant microbiota of Sudanese fermented milk Rob. Int. Dairy J. 2001, 11, 63-70. [CrossRef]

6. de Souza Rodrigues, J.Z.; Passos, M.R.; de Macêdo Neres, N.S.; Almeida, R.S.; Pita, L.S.; Santos, I.A.; Silveira, P.H.S.; Reis, M.M.; Santos, I.P.; Ricardo, L.d.O.N. Antimicrobial activity of Lactobacillus fermentum TcUESC01 against Streptococcus mutans UA159. Microb. Pathog. 2020, 142, 104063. [CrossRef]

7. Park, J.-H.; Lee, Y.; Moon, E.; SEOK, S.-H.; BAEK, M.-W.; LEE, H.-Y.; KIM, D.-J.; KIM, C.-H.; Park, J.-H. Safety assessment of Lactobacillus fermentum PL9005, a potential probiotic lactic acid bacterium, in mice. J. Microbiol. Biotechnol. 2005, 15, 603-608.

8. Gardiner, G.E.; Heinemann, C.; Baroja, M.L.; Bruce, A.W.; Beuerman, D.; Madrenas, J.n.; Reid, G. Oral administration of the probiotic combination Lactobacillus rhamnosus GR-1 and L. fermentum RC-14 for human intestinal applications. Int. Dairy J. 2002, 12, 191-196. [CrossRef]

9. Sadeghi, A. In vitro Assessment of Some Probiotic Properties of Lactobacillus fermentum Isolated from Pickled Garlic. J. Food Qual. Hazards Control 2016, 3, 67-72.

10. Anukam, K.; Reid, G. Lactobacillus plantarum and Lactobacillus fermentum with probiotic potentials isolated from the vagina of healthy Nigerian women. Res. J. Microbiol. 2007, 2, 81-87.

11. Kaur, B.; Balgir, P.; Mittu, B.; Chauhan, A.; Kumar, B. Purification and physicochemical characterization of anti-Gardnerella vaginalis bacteriocin $\mathrm{HV} 6 \mathrm{~b}$ produced by Lactobacillus fermentum isolate from human vaginal ecosystem. Am. J. Biochem. Mol. Biol. 2013, 3, 91-100. [CrossRef]

12. Fuochi, V.; Li Volti, G.; Furneri, P.M. Probiotic properties of Lactobacillus fermentum strains isolated from human oral samples and description of their antibacterial activity. Curr. Pharm. Biotechnol. 2017, 18, 138-149. [CrossRef] [PubMed]

13. EFSA Panel on Biological Hazards; Koutsoumanis, K.; Allende, A.; Alvarez-Ordóñez, A.; Bolton, D.; Bover-Cid, S.; Chemaly, M.; Davies, R.; De Cesare, A.; Hilbert, F. Update of the list of QPS-recommended biological agents intentionally added to food or feed as notified to EFSA 12: Suitability of taxonomic units notified to EFSA until March 2020. EFSA J. 2020, 18, e06174. [PubMed]

14. FAO/WHO. Evaluation of Certain Food Additives: Seventy-Ninth Report of the Joint FAO/WHO Expert Committee on Food Additives; World Health Organization: Geneva, Switzerland, 2015; Volume 79.

15. Castellano, P.; Pérez Ibarreche, M.; Blanco Massani, M.; Fontana, C.; Vignolo, G.M. Strategies for pathogen biocontrol using lactic acid bacteria and their metabolites: A focus on meat ecosystems and industrial environments. Microorganisms 2017, 5, 38. [CrossRef]

16. Gálvez, A.; Abriouel, H.; López, R.L.; Omar, N.B. Bacteriocin-based strategies for food biopreservation. Int. J. Food Microbiol. 2007, 120, 51-70. [CrossRef]

17. Mokoena, M.P. Lactic acid bacteria and their bacteriocins: Classification, biosynthesis and applications against uropathogens: A mini-review. Molecules 2017, 22, 1255. [CrossRef] [PubMed]

18. Gharsallaoui, A.; Oulahal, N.; Joly, C.; Degraeve, P. Nisin as a food preservative: Part 1: Physicochemical properties, antimicrobial activity, and main uses. Crit. Rev. Food Sci. Nutr. 2016, 56, 1262-1274. [CrossRef]

19. Guinane, C.; Cotter, P.; Hill, C.; Ross, R. Microbial solutions to microbial problems; lactococcal bacteriocins for the control of undesirable biota in food. J. Appl. Microbiol. 2005, 98, 1316-1325. [CrossRef] [PubMed]

20. Punyauppa-path, S.; Phumkhachorn, P.; Rattanachaikunsopon, P. Nisin: Production and mechanism of antimicrobial action. Int. J. Curr. Res. Rev. 2015, 7, 47.

21. Shahidi, F.; Chandrasekara, A. Millet grain phenolics and their role in disease risk reduction and health promotion: A review. J. Funct. Foods 2013, 5, 570-581. [CrossRef]

22. Chandra, D.; Chandra, S.; Sharma, A. Review of Finger millet (Eleusine coracana (L.) Gaertn): A power house of health benefiting nutrients. Food Sci. Hum. Wellness 2016, 5, 149-155. [CrossRef]

23. Taylor, J.R. Millets: Their unique nutritional and health-promoting attributes. In Gluten-Free Ancient Grains; Elsevier: Amsterdam, The Netherlands, 2017; pp. 55-103.

24. Saleh, A.S.; Zhang, Q.; Chen, J.; Shen, Q. Millet grains: Nutritional quality, processing, and potential health benefits. Compr. Rev. Food Sci. Food Saf. 2013, 12, 281-295. [CrossRef]

25. Hancioğlu, Ö.; Karapinar, M. Microflora of Boza, a traditional fermented Turkish beverage. Int. J. Food Microbiol. 1997, 35, $271-274$. [CrossRef]

26. Zorba, M.; Hancioglu, O.; Genc, M.; Karapinar, M.; Ova, G. The use of starter cultures in the fermentation of boza, a traditional Turkish beverage. Process Biochem. 2003, 38, 1405-1411. [CrossRef] 
27. Rasheed, H.A.; Tuoheti, T.; Zhang, Y.; Azi, F.; Tekliye, M.; Dong, M. Purification and partial characterization of a novel bacteriocin produced by bacteriocinogenic Lactobacillus fermentum BZ532 isolated from Chinese fermented cereal beverage (Bozai). LWT 2020, 124, 109113. [CrossRef]

28. Todorov, S.; Nyati, H.; Meincken, M.; Dicks, L. Partial characterization of bacteriocin AMA-K, produced by Lactobacillus plantarum AMA-K isolated from naturally fermented milk from Zimbabwe. Food Control 2007, 18, 656-664. [CrossRef]

29. Todorov, S.; Dicks, L. Pediocin ST18, an anti-listerial bacteriocin produced by Pediococcus pentosaceus ST18 isolated from boza, a traditional cereal beverage from Bulgaria. Process Biochem. 2005, 40, 365-370. [CrossRef]

30. de Castilho, N.P.A.; Todorov, S.D.; Oliveira, L.L.; dos Santos Bersot, L.; Nero, L.A. Inhibition of Listeria monocytogenes in fresh sausage by bacteriocinogenic Lactobacillus curvatus UFV-NPAC1 and its semi-purified bacteriocin. LWT 2020, $118,108757$. [CrossRef]

31. Cuniffe, P. Official Methods of Analysis of the Association of Official Analytical Chemists, 16th ed.; AOAC International: Washington, DC, USA, 1995.

32. AACC. Approved Methods of the American Association of Cereal Chemists, 10th ed.; American Association of Cereal Chemists: St. Paul, MN, USA, 2000; Volume 1.

33. AOAC. Official Methods of Analysis, 13th ed.; AOAC International: Washington, DC, USA, 1980; Volume 13.

34. Arslan, S.; Durak, A.N.; Erbas, M.; Tanriverdi, E.; Gulcan, U. Determination of microbiological and chemical properties of probiotic boza and its consumer acceptability. J. Am. Coll. Nutr. 2015, 34, 56-64. [CrossRef]

35. Chen, C.; Rui, X.; Lu, Z.; Li, W.; Dong, M. Enhanced shelf-life of tofu by using bacteriocinogenic Weissella hellenica D1501 as bioprotective cultures. Food Control 2014, 46, 203-209. [CrossRef]

36. Osimani, A.; Garofalo, C.; Aquilanti, L.; Milanović, V.; Clementi, F. Unpasteurised commercial boza as a source of microbial diversity. Int. J. Food Microbiol. 2015, 194, 62-70. [CrossRef] [PubMed]

37. Pateiro, M.; Vargas, F.C.; Chincha, A.A.; Sant'Ana, A.S.; Strozzi, I.; Rocchetti, G.; Barba, F.J.; Domínguez, R.; Lucini, L.; do Amaral Sobral, P.J. Guarana seed extracts as a useful strategy to extend the shelf life of pork patties: UHPLC-ESI/QTOF phenolic profile and impact on microbial inactivation, lipid and protein oxidation and antioxidant capacity. Food Res. Int. 2018, 114, 55-63. [CrossRef] [PubMed]

38. Öztürk, İ.; Karaman, S.; Törnük, F.; Sağdiç, O. Physicochemical and rheological characteristics of alcohol free probiotic boza produced using Lactobacillus casei Shirota: Estimation of apparent viscosity of boza using non-linear modeling techniques. Turk. J. Agric. For. 2013, 37, 475-487. [CrossRef]

39. Barbosa, M.; Todorov, S.; Belguesmia, Y.; Choiset, Y.; Rabesona, H.; Ivanova, I.; Chobert, J.M.; Haertlé, T.; Franco, B. Purification and characterization of the bacteriocin produced by L actobacillus sakei MBS a1 isolated from B razilian salami. J. Appl. Microbiol. 2014, 116, 1195-1208. [CrossRef] [PubMed]

40. Schillinger, U.; Becker, B.; Vignolo, G.; Holzapfel, W. Efficacy of nisin in combination with protective cultures against Listeria monocytogenes Scott A in tofu. Int. J. Food Microbiol. 2001, 71, 159-168. [CrossRef]

41. Cotter, P.D.; Hill, C.; Ross, R.P. Bacteriocins: Developing innate immunity for food. Nat. Rev. Microbiol. 2005, 3, 777-788. [CrossRef]

42. Aspri, M.; O'Connor, P.M.; Field, D.; Cotter, P.D.; Ross, P.; Hill, C.; Papademas, P. Application of bacteriocin-producing Enterococcus faecium isolated from donkey milk, in the bio-control of Listeria monocytogenes in fresh whey cheese. Int. Dairy J. 2017, 73, 1-9. [CrossRef]

43. Kivanc, M.; Yilmaz, M.; Çakir, E. Isolation and identification of lactic acid bacteria from boza, and their microbial activity against several reporter strains. Turk. J. Biol. 2011, 35, 313-324.

44. Russo, P.; de Chiara, M.L.V.; Capozzi, V.; Arena, M.P.; Amodio, M.L.; Rascón, A.; Dueñas, M.T.; López, P.; Spano, G. Lactobacillus plantarum strains for multifunctional oat-based foods. Lwt-Food Sci. Technol. 2016, 68, 288-294. [CrossRef]

45. Helland, M.H.; Wicklund, T.; Narvhus, J.A. Growth and metabolism of selected strains of probiotic bacteria, in maize porridge with added malted barley. Int. J. Food Microbiol. 2004, 91, 305-313. [CrossRef]

46. Kockova, M.; Valík, L'. Development of new cereal-, pseudocereal-, and cereal-leguminous-based probiotic foods. Czech J. Food Sci. 2014, 32, 391-397. [CrossRef]

47. Arslan-Tontul, S.; Erbas, M. Co-Culture probiotic fermentation of protein-enriched cereal medium (Boza). J. Am. Coll. Nutr. 2020, 39, 72-81. [CrossRef]

48. do Amaral Santos, C.C.A.; da Silva Libeck, B.; Schwan, R.F. Co-culture fermentation of peanut-soy milk for the development of a novel functional beverage. Int. J. Food Microbiol. 2014, 186, 32-41. [CrossRef] [PubMed]

49. Cotter, P.D.; Hill, C. Surviving the acid test: Responses of gram-positive bacteria to low pH. Microbiol. Mol. Biol. Rev. 2003, 67, 429-453. [CrossRef] [PubMed] 